\title{
Self-reported attitudes versus actual practice of oxygen therapy by ICU physicians and nurses
}

\author{
Hendrik JF Helmerhorst ${ }^{1,2^{*}}$, Marcus J Schultz ${ }^{2,3}$, Peter HJ van der Voort ${ }^{4}$, Robert J Bosman ${ }^{4}$, Nicole P Juffermans ${ }^{2,3}$, \\ Evert de Jonge ${ }^{1}$ and David J van Westerloo ${ }^{1}$
}

\begin{abstract}
Background: High inspiratory oxygen concentrations are frequently administered in ventilated patients in the intensive care unit (ICU) but may induce lung injury and systemic toxicity. We compared beliefs and actual clinical practice regarding oxygen therapy in critically ill patients.

Methods: In three large teaching hospitals in the Netherlands, ICU physicians and nurses were invited to complete a questionnaire about oxygen therapy. Furthermore, arterial blood gas (ABG) analysis data and ventilator settings were retrieved to assess actual oxygen practice in the same hospitals 1 year prior to the survey.

Results: In total, 59\% of the 215 respondents believed that oxygen-induced lung injury is a concern. The majority of physicians and nurses stated that minimal acceptable oxygen saturation and partial arterial oxygen pressure $\left(\mathrm{PaO}_{2}\right)$ ranges were $85 \%$ to $95 \%$ and 7 to $10 \mathrm{kPa}(52.5$ to $75 \mathrm{mmHg})$, respectively. Analysis of $107,888 \mathrm{ABG}$ results with concurrent ventilator settings, derived from 5,565 patient admissions, showed a median (interquartile range (IQR)) $\mathrm{PaO}_{2}$ of $11.7 \mathrm{kPa}$ (9.9 to 14.3 ) [87.8 mmHg], median fractions of inspired oxygen $\left(\mathrm{FiO}_{2}\right)$ of 0.4 (0.4 to 0.5$)$, and median positive end-expiratory pressure (PEEP) of $5(5$ to 8$) \mathrm{cm} \mathrm{H}_{2} \mathrm{O}$. Of all $\mathrm{PaO}_{2}$ values, $73 \%$ were higher than the upper limit of the commonly self-reported acceptable range, and in $58 \%$ of these cases, neither $\mathrm{FiO}_{2}$ nor PEEP levels were lowered until the next ABG sample was taken.
\end{abstract}

Conclusions: Most ICU clinicians acknowledge the potential adverse effects of prolonged exposure to hyperoxia and report a low tolerance for high oxygen levels. However, in actual clinical practice, a large proportion of their ICU patients was exposed to higher arterial oxygen levels than self-reported target ranges.

Keywords: Oxygen; Hyperoxia; Mechanical ventilation; Lung injury; Intensive care medicine; Questionnaire

\section{Background}

Oxygen supply during mechanical ventilation is a highly effective and uniformly used intervention to support oxygenation of mechanically ventilated patients in the intensive care unit (ICU). Although oxygen administration is a lifesaving strategy in the management of patients with respiratory insufficiency, the clinical implications of hyperoxia remain an important subject of debate [1]. The controversies are triggered by a considerable number of studies showing beneficial, harmful, and/or insignificant effects of oxygen therapy on outcome in different

\footnotetext{
* Correspondence: H.J.F.Helmerhorst@lumc.nl

${ }^{1}$ Department of Intensive Care Medicine, Leiden University Medical Center,

Post Box 9600, Leiden 2300, RC, The Netherlands

${ }^{2}$ Laboratory of Experimental Intensive Care and Anesthesiology,

Academic Medical Center, Amsterdam 1105, AZ, The Netherlands

Full list of author information is available at the end of the article
}

subgroups [2-15]. However, morbidity and mortality may be substantially impacted by the used threshold and depend on degree, duration, and susceptibility for hyperoxia.

The emerging laboratory evidence for the double-edged nature of oxygen (lifesaving but also potentially harmful) is compelling [16-22], but robust clinical studies and evidence-based guidelines in critically ill patients are still limited [23-26]. Consequently, the attitudes and beliefs in the management of oxygen administration vary considerably in clinical practice $[27,28]$. In general, physicians are inclined to treat hypoxemia aggressively in order to achieve satisfactory tissue oxygenation $[23,29,30]$. However, hyperoxemia is often considered acceptable, especially when applied fractions of inspired oxygen $\left(\mathrm{FiO}_{2}\right)$ are relatively low [31-33].

\section{实}


Given the lack of established guidelines on oxygen therapy in ICU patients, our study was designed to investigate the common beliefs and self-reported attitudes of ICU physicians and nurses on oxygenation targets and to compare this with actual treatment of ICU patients in the same hospitals. We hypothesized that the potential harmful effects of oxygen are well known and generally acknowledged, but that in real clinical practice, hyperoxia is not a major concern for ICU professionals.

\section{Methods}

\section{Questionnaire}

An anonymous online survey was performed between June and August 2012 to elicit the self-reported behavior of ICU personnel with respect to oxygen therapy. The questionnaire was a modified and comprehensive version of previously used questionnaires from Canada and Australia/New Zealand [27,28] and comprised multiple choice questions (see Additional file 1). The target population consisted of physicians and nurses, working in closed format, mixed medical and surgical, tertiary care ICUs of three participating hospitals, including two academic and one large teaching hospital in the Netherlands. Participants were invited by email to complete the online questionnaire. A reminder was sent once to all participants.

\section{Patient data}

Analyses were performed on data recorded between 1 April 2011 and 31 March 2012 for all patients admitted to the ICU departments of the same hospitals that participated in the questionnaire study. Anonymous encrypted data were collected from the patient data management system (PDMS) database (MetaVision, iMDsoft, Leiden, The Netherlands). According to the Dutch Medical Research Involving Human Subjects Act, there was no need for informed patient consent or approval by ethical committees, as only registries without patient identifying information were used.

Arterial blood gas (ABG) analyses and concurrent ventilator settings were extracted to retrospectively assess actual practices regarding oxygen therapy. Data from ICU admission to dismissal or death were included for analysis. Data with a partial arterial oxygen pressure $\left(\mathrm{PaO}_{2}\right)$ of $\leq 4.5 \mathrm{kPa}$ or $33.8 \mathrm{mmHg}(n=209)$ were excluded to prevent confounding by venous blood gas samples. Further exclusion of samples with $\mathrm{PaO}_{2}$ of 4.5 to $5.0 \mathrm{kPa}(n=146)$ or $\mathrm{PaO}_{2}$ of 5.0 to $6.0 \mathrm{kPa}(n=356)$ did not materially change our observations (data not shown). Every set of ABG data and ventilator settings was compared with the following set, as described previously [32]. Prone positioning, recruitment maneuvers, and other efforts that may improve oxygenation could not be explored in this database. Clinicians' responses to ABG results were explored by analyzing the $\mathrm{FiO}_{2}$ and positive end-expiratory pressure (PEEP) adjustments in a subsample of mechanically ventilated patients when more than two ABG samples and ventilator settings were recorded. $\mathrm{PaO}_{2}$ values were categorized according to the commonly self-reported acceptable range ( 7 to 10 $\mathrm{kPa}$ or 52.5 to $75 \mathrm{mmHg}$ ) extracted from the survey results (Figure 1). This range is roughly consistent with

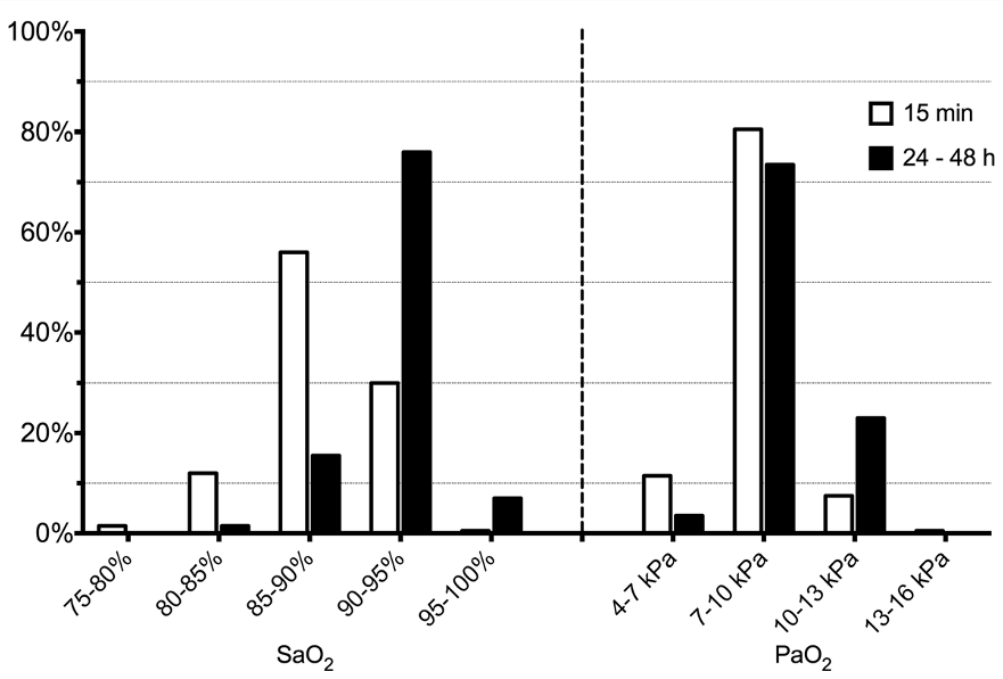

Figure 1 Self-reported tolerance limits for short-term ( $15 \mathrm{~min}$, open bars) and longer term ( 24 to $48 \mathrm{~h}$, closed bars) oxygenation. Bars represent percentage of respondents $(n=200)$. The presented case is a young to middle-aged ARDS patient in the ICU requiring mechanical ventilation. Ventilator settings (e.g., PEEP, airway pressures, l/E ratio, flow ratio) are optimized with respect to the $\mathrm{PaO}_{2} / \mathrm{FiO}_{2}$ ratio and hemodynamic indices. Lung injury due to high $\mathrm{FiO}_{2}$ and/or ventilator settings is minimized. There is no evidence to indicate end-organ ischemia, and hemodynamics are stable. 
oxygenation goals (7.3 to $10.7 \mathrm{kPa}$ or 55 to $80 \mathrm{mmHg}$ ) previously suggested by the Acute Respiratory Distress Syndrome (ARDS) network [30,34].

\section{Mechanical ventilation protocol}

Local guidelines, applicable during the survey and collection of $A B G$ and ventilation data, instructed for lowest acceptable $\mathrm{FiO}_{2}$ levels. $\mathrm{FiO}_{2}$ levels higher than $60 \%$ should be avoided by increasing PEEP levels, instituting inverse-ratio ventilation or prone positioning. No explicit target ranges for $\mathrm{PaO}_{2}, \mathrm{FiO}_{2}$, or saturation were specified in the participating hospitals during this period.

\section{Statistical analysis}

All data are expressed as percentages of the total number of respondents for the particular questions, unless otherwise specified. Data are presented as means $( \pm$ SD) or medians (interquartile range (IQR)) depending on data distributions, unless stated otherwise. For assessing differences between physicians and nurses, ICU personnel were grouped according to their respective profession and data were analyzed using Fisher's exact tests. ICU physicians, fellows, and residents were classified as physicians; ICU nurses and ICU nurses in training were classified as nurses.

Statistical analyses were conducted using STATA/SE 10.1 (StataCorp LP, College Station, TX, USA).

\section{Results}

Data derived from questionnaire

Respondent characteristics

Approximately 500 potential participants were invited to complete the online questionnaire. Full or partial responses were received from 215 ICU physicians and nurses with a mean age of $40.4 \pm 10.0$ years (range 24 to 62). In total, $171(80 \%)$ respondents fully completed all questions. The group of respondents consisted of 28 (13\%) critical care physicians, 15 (7\%) fellows, 15 (7\%) residents, 141 (66\%) ICU nurses, 11 (5\%) ICU nurses in training, and 5 (2\%) ICU clinicians with another type of practice.

\section{Opinions towards oxygen toxicity}

The responses are listed in Table 1. Overall, 126 (59\%) respondents considered oxygen-induced lung injury in mechanically ventilated patients a major concern. However, the vast majority of respondents (81\%) considered high tidal volumes and high inspiratory pressures as the greatest risk for lung injury in mechanically ventilated patients. No differences between physicians and nurses were detected.

\section{Self-reported acceptance of hyperoxemia and hypoxemia}

The percentages of respondents accepting various oxygenation ranges in a young to middle-aged mechanically ventilated patient with ARDS are shown in Figure 1.

Table 1 Questionnaire responses regarding risks assessment and management in oxygen therapy

\begin{tabular}{|c|c|c|}
\hline Question & Responses (\% of total) & Physicians vs. nurses \\
\hline Is oxygen induced lung injury a concern when placing a patient on mechanical ventilation? & & NS \\
\hline YES, a major concern & $126(59 \%)$ & \\
\hline due to the high incidence of injury & $13(6 \%)$ & \\
\hline due to the severity of injury & $63(29 \%)$ & \\
\hline due to the high incidence and severity of injury & $50(23 \%)$ & \\
\hline YES, but not a major concern & $80(37 \%)$ & \\
\hline $\mathrm{NO}$, it is not a concern & $9(4 \%)$ & \\
\hline $\begin{array}{l}\text { In your opinion, which one of the following two situations poses a greater threat of lung injury } \\
\text { for mechanically ventilated patients? }\end{array}$ & & NS \\
\hline High $\mathrm{FiO}_{2}$ & $35(16 \%)$ & \\
\hline High tidal volumes and high ventilator pressures & $173(81 \%)$ & \\
\hline Don't know & $7(3 \%)$ & \\
\hline $\begin{array}{l}\text { In situations when maximal } \mathrm{SaO}_{2} \text { achievable is low }( \pm 85 \%) \text { or when } \mathrm{FiO}_{2} \text { requirements are high, } \\
\text { do you assess indices of tissue oxygenation? }\end{array}$ & & $P=0.05$ \\
\hline NO & $91(43 \%)$ & \\
\hline YES, lactate & $88(42 \%)$ & \\
\hline YES, microcirculation with OPS/SDF imaging & $4(2 \%)$ & \\
\hline YES, a combination of indices & $20(9 \%)$ & \\
\hline YES, $\mathrm{SVO}_{2}$ & $6(3 \%)$ & \\
\hline YES, other & $2(1 \%)$ & \\
\hline
\end{tabular}

$\mathrm{NS}$, not significant; $\mathrm{FiO}_{2}$, fractions of inspired oxygen; OPS, orthogonal polarization spectral; SDF, sidestream dark field; SaO ${ }_{2}$, arterial oxygen saturation; $\mathrm{SvO}_{2}$, mixed venous oxygen saturation. 
For both short and longer lasting periods, the vast majority of respondents choose 7 to $10 \mathrm{kPa}$ (52.5 to 75 mmHg) as the lowest acceptable $\mathrm{PaO}_{2}$ range. Physicians were more tolerant towards lower $\mathrm{PaO}_{2}$ limits for short duration than nurses $(P<0.001)$.

Presented with a patient whose arterial oxygen saturation $\left(\mathrm{SaO}_{2}\right)$ levels are low $(<85 \%)$ or $\mathrm{FiO}_{2}$ requirements are high, indices of tissue oxygenation were frequently assessed (Table 1). Differences between physicians and nurses approached statistical significance $(P=0.05)$, with physicians favoring lactate assessment and nurses being less likely to demand some assessment of tissue oxygenation. Nurses in training more often favored lactate assessment than senior ICU nurses $(P=0.01)$.

\section{Adjustment of $\mathrm{FiO}_{2}$ in specific clinical cases}

The proportions of ICU clinicians adjusting $\mathrm{FiO}_{2}$ levels in specified clinical cases are listed in Table 2. Observed differences by profession were mainly restricted to questions regarding patients with untreatable anemia, where physicians generally favored higher $\mathrm{FiO}_{2}$ levels than nurses. Only minor differences within the clustered categories of physicians (comparison between physicians, fellows, residents) and nurses (ICU nurses, nurses in training) were observed.

\section{Data derived from ABG measurements and ventilator settings \\ Descriptive data}

A total of 107,888 ABG results with concurrent ventilator settings, covering 5,565 patient admissions, were retrieved and included for analysis over a 1 -year period prior to the survey in three hospitals. Median interval between two consecutive ABG samples was 214 min (IQR 130 to 331), and the median number of ABG samples per patient was 7 (IQR 4 to 19). Mean $\mathrm{PaO}_{2}$ was $12.9 \mathrm{kPa}$ (SD 5.1) or 96.8 mmHg, and median $\mathrm{PaO}_{2}$ was $11.7 \mathrm{kPa}$ (IQR 9.9 to 14.3) or $87.8 \mathrm{mmHg}$. Overall, in $25.3 \%$ of ABG results, $\mathrm{PaO}_{2}$ was in the self-reported range (7 to $10 \mathrm{kPa}$ ), $1.2 \%$ was lower and $73.4 \%$ was higher than the predefined range.

Mechanical ventilation settings showed a mean PEEP of $6.1 \mathrm{~cm} \mathrm{H}_{2} \mathrm{O}$ (SD 4.3), and median PEEP was 5 (IQR 5 to 8). Mean $\mathrm{FiO}_{2}$ was 0.45 (SD 0.14), and median $\mathrm{FiO}_{2}$ was 0.40 (IQR 0.40 to 0.50 ). Only small differences were observed between the three participating hospitals.

\section{Recorded $\mathrm{FiO}_{2}$ adjustments following ABG analysis}

After exclusion of spontaneously breathing and noninvasively ventilated patients, 62,875 ABG records derived from 4,264 mechanically ventilated patients were included for analysis of $\mathrm{FiO}_{2}$ adjustments in response to ABG samples.

Analyzing every first registered ABG sample in the ICU, 62,222 $\mathrm{PaO}_{2}$ measurements covering 3,791 patients were retrospectively categorized in predefined ranges and were followed by a recorded $\mathrm{FiO}_{2}$ adjustment. The subsequently registered $\mathrm{PaO}_{2}$ measurement was compared with the first registered $\mathrm{PaO}_{2}$ (Table 3).

Table 4 shows that quantity, direction, and magnitude of ventilator adjustments in response to high arterial oxygen levels are considerably influenced by the level of $\mathrm{FiO}_{2}$. In $58.3 \%$ of cases with $\mathrm{PaO}_{2}$ higher than the upper level of the commonly self-reported acceptable oxygenation (10 $\mathrm{kPa}$ or $75 \mathrm{mmHg}$ ), neither $\mathrm{FiO}_{2}$ nor PEEP levels had been lowered when the next ABG sample was taken.

\section{Discussion}

In accordance with accumulating laboratory evidence for the toxic effects of oxygen in pulmonary injury [1,35-38], the majority of surveyed ICU physicians and nurses consider prolonged hyperoxic exposure to be associated with an increased risk for lung injury, although a lower risk than high tidal volumes and inspiratory pressures. In contrast, in actual clinical practice, the majority of $\mathrm{PaO}_{2}$ values recorded in ICU patients are higher than recommended targets under comparable conditions and are generally accepted by ICU physicians and nurses without adjustment of ventilator settings.

Compared with previous studies from other countries, more respondents identified oxygen toxicity as a major threat to lung injury in ICU patients (59\% compared with $26 \%$ and $51 \%$ in studies from Australia and Canada, respectively) $[27,28]$. Similar proportions of respondents considered high inspiratory oxygen concentrations a more important risk than high tidal volumes or inspiratory pressures, and a similar heterogeneity in self-reported attitudes regarding oxygen therapy was observed [27,28,39]. The current results show generally higher minimum allowable $\mathrm{SaO}_{2}$ ranges than data from Canadian intensivists [28], which may indicate that clinicians' beliefs have changed over the last decade or it may merely reflect geographical differences in oxygen therapy.

It appears that clinicians' opinions regarding optimal oxygen therapy are more variable in case $\mathrm{SaO}_{2}$ is presented compared to $\mathrm{PaO}_{2}$ as marker of oxygenation. For $\mathrm{PaO}_{2}$, the vast majority of clinicians choose 7 to $10 \mathrm{kPa}$ (52.5 to $75 \mathrm{mmHg}$ ), whereas the preferred targets for saturation varied between $85 \%$ and $95 \%$. Assuming that oxygenation targets should be in line with the best evidence in available guidelines, these preferred ranges may be triggered by recommendations and protocols providing comparable $\mathrm{PaO}_{2}$ targets $[30,40]$. However, caution is urged when interpreting pulse oximetry to differentiate between hyperoxemia and normoxia. Saturation levels above $95 \%$ require special attention, since the corresponding $\mathrm{PaO}_{2}$ levels usually cover a wide range and may substantially exceed target levels [24,41]. 
Table 2 Percentages of respondents adjusting $\mathrm{FiO}_{2}$ levels in specified clinical conditions with presented levels of arterial oxygenation

\begin{tabular}{|c|c|c|c|c|c|c|c|c|c|c|c|c|c|c|c|}
\hline & \multicolumn{3}{|c|}{$\begin{array}{l}\text { ARDS } \\
\mathrm{FiO}_{2} \text { response }\end{array}$} & \multicolumn{3}{|c|}{$\begin{array}{l}\text { Cardiac ischemia } \\
\mathrm{FiO}_{2} \text { response }\end{array}$} & \multicolumn{3}{|c|}{$\begin{array}{l}\text { Cerebral ischemia } \\
\mathrm{FiO}_{2} \text { response }\end{array}$} & \multicolumn{3}{|c|}{$\begin{array}{l}\text { Sepsis } \\
\mathrm{FiO}_{2} \text { response }\end{array}$} & \multicolumn{3}{|c|}{$\begin{array}{l}\text { Untreatable anemia } \\
\mathrm{FiO}_{2} \text { response }\end{array}$} \\
\hline & Higher & Unchanged & Lower & Higher & Unchanged & Lower & Higher & Unchanged & Lower & Higher & Unchanged & Lower & Higher & Unchanged & Lower \\
\hline \multicolumn{16}{|l|}{$\mathrm{SaO}_{2}$} \\
\hline $80 \%$ to $85 \%$ & 97.4 & 2.6 & 0.0 & 100 & 0.0 & 0.0 & 98.9 & 1.1 & 0.0 & 99.5 & 0.5 & 0.0 & 92.4 & 7.1 & 0.5 \\
\hline $85 \%$ to $90 \%$ & 61.5 & 38.5 & 0.0 & 96.4 & 3.6 & 0.0 & 91.4 & 8.0 & 0.5 & 92.5 & 7.0 & 0.5 & 85.3 & 13.6 & 1.1 \\
\hline $90 \%$ to $95 \%$ & 4.1 & 78.5 & 17.4 & 42.6 & 54.9 & 2.6 & 23.0 & 71.7 & 5.3 & 19.3 & 75.9 & 4.8 & 57.6 & 36.4 & 6.0 \\
\hline $95 \%$ to $100 \%$ & 0.0 & 17.4 & 82.6 & 2.6 & 61.0 & 36.4 & 0.5 & 41.2 & 58.3 & 0.5 & 40.1 & 59.4 & 13.6 & 58.7 & 27.7 \\
\hline \multicolumn{16}{|l|}{$\mathrm{PaO}_{2}$} \\
\hline $6 \mathrm{kPa}$ & 96.6 & 3.4 & 0.0 & 98.3 & 1.7 & 0.0 & 98.3 & 1.7 & 0.0 & 98.3 & 1.7 & 0.0 & 96.5 & 3.5 & 0.0 \\
\hline $9 \mathrm{kPa}$ & 9.0 & 85.3 & 5.6 & 60.1 & 38.2 & 1.7 & 40.6 & 58.9 & 0.6 & 37.7 & 60.6 & 1.7 & 66.7 & 31.6 & 1.8 \\
\hline $12 \mathrm{kPa}$ & 0.6 & 27.1 & 72.3 & 5.6 & 60.7 & 33.7 & 2.3 & 53.7 & 44.0 & 2.9 & 47.4 & 49.7 & 22.2 & 52.6 & 25.1 \\
\hline $16 \mathrm{kPa}$ & 0.0 & 2.3 & 97.7 & 2.2 & 10.1 & 87.6 & 1.1 & 4.6 & 94.3 & 0.6 & 7.4 & 92.0 & 6.4 & 25.7 & 67.8 \\
\hline
\end{tabular}

All clinical situations represent patients in the ICU, who have been invasively mechanically ventilated for at least 5 days, with $\mathrm{FiO}_{2}$ set at $50 \%$. ARDS = patient with acute respiratory distress syndrome and pneumonia; cardiac ischemia = patient with signs of cardiac ischemia (ST-depressions in the anterior leads [max $3 \mathrm{~mm}]$ ) and pneumonia; cerebral ischemia = patient with recent cerebral ischemia and one-sided hemiplegia; sepsis = patient with a liver abscess and sepsis; untreatable anemia = Jehovah's Witness with stable hemoglobin of $1.8 \mathrm{mmol} / \mathrm{L}$ after gastric bleeding; higher $=$ increase $\mathrm{FiO}_{2}$, higher than $\mathrm{current}_{50}$; ; unchanged $=\mathrm{maintain}_{\mathrm{FiO}}$ at current 50\%; lower = decrease $\mathrm{FiO}_{2}$, lower than current $50 \%$. 
Table $3 \mathrm{FiO}_{2}$ adjustment following ABG analysis and its effects on oxygenation measured in the next ABG

\begin{tabular}{|c|c|c|c|c|}
\hline \multirow{2}{*}{$\begin{array}{l}\mathrm{PaO}_{2}(\%) \\
{[n=107,888]}\end{array}$} & \multirow{2}{*}{$\begin{array}{l}\text { Adjustment of } \\
\mathrm{FiO}_{2}(\%) \\
{[n=62,222]}\end{array}$} & \multicolumn{3}{|c|}{$\begin{array}{c}\text { Successive } \mathrm{PaO}_{2} \\
{[n=61,073]}\end{array}$} \\
\hline & & $\begin{array}{l}\text { Higher } \\
\left(\text { Delta } \mathrm{PaO}_{2}\right)\end{array}$ & Unchanged & $\begin{array}{l}\text { Lower } \\
\left(\text { Delta } \mathrm{PaO}_{2}\right)\end{array}$ \\
\hline \multirow[t]{3}{*}{$<7 \mathrm{kPa}(1.2)$} & Higher (34.7) & $96.6 \%(+5.3)$ & $0.4 \%$ & $3.0 \%(-0.5)$ \\
\hline & Unchanged (46.9) & $87.4 \%(+5.6)$ & $3.2 \%$ & $9.4 \%(-0.6)$ \\
\hline & Lower (18.4) & $95.1 \%(+7.9)$ & $2.4 \%$ & $2.5 \%(-0.9)$ \\
\hline \multirow[t]{3}{*}{7 to $10 \mathrm{kPa}(25.3)$} & Higher (27.9) & $76.3 \%(+3.1)$ & $2.7 \%$ & $21.0 \%(-0.9)$ \\
\hline & Unchanged (56.0) & $66.3 \%(+2.0)$ & $4.3 \%$ & $29.4 \%(-0.8)$ \\
\hline & Lower (16.1) & $61.3 \%(+2.6)$ & $3.6 \%$ & $35.1 \%(-1.0)$ \\
\hline \multirow[t]{3}{*}{$>10 \mathrm{kPa}(73.4)$} & Higher (10.8) & $48.6 \%(+4.6)$ & $2.1 \%$ & $49.3 \%(-3.1)$ \\
\hline & Unchanged (62.0) & $44.7 \%(+2.1)$ & $3.1 \%$ & $52.2 \%(-2.3)$ \\
\hline & Lower (27.2) & $23.5 \%(+2.4)$ & $1.7 \%$ & $74.8 \%(-4.6)$ \\
\hline Total (100) & - & $46.3 \%(+2.6)$ & $2.7 \%$ & $51.0 \%(-2.9)$ \\
\hline
\end{tabular}

Data presented as percentages of total and irrespective of adjustment of other ventilator settings (e.g., $\mathrm{PEEP}, \mathrm{I} / \mathrm{E}$ ratio). $\mathrm{PaO}{ }_{2}=\mathrm{any}_{\mathrm{fecorded}} \mathrm{PaO} \mathrm{O}_{2}$ stratified by self-reported ranges; successive $\mathrm{PaO}_{2}=\mathrm{PaO}_{2}$ from successively registered $\mathrm{ABG}$ sample; Delta = mean difference between two successive $\mathrm{ABG}$ samples; Higher = increased $\mathrm{FiO}_{2}$ (column 2) or $\mathrm{PaO}_{2}$ (column 3), higher than previous level; unchanged $=\mathrm{FiO}_{2}$ or $\mathrm{PaO}_{2}$ equal to previous level; lower $=$ decreased FiO ${ }_{2}$ or $\mathrm{PaO}$, lower than previous level. A total of $62,222 \mathrm{PaO}_{2}$ measurements from 3,791 patients $(57.7 \%$ of all $107,888 \mathrm{ABG}$ samples) in the database is followed by an adjustment of ventilator settings, and $98.2 \%$ of $\mathrm{PO}_{2}$ measurements is followed by a successive $\mathrm{PO}_{2}$ measurement $(n=61,073)$ in the same patient when adjustment of FiO $\mathrm{O}_{2}$ is also measured.

According to the results from our questionnaire, the vast majority of respondents stated they would lower $\mathrm{FiO}_{2}$ levels if $\mathrm{PaO}_{2}$ was higher than $12 \mathrm{kPa}(90 \mathrm{mmHg})$ or $\mathrm{SaO}_{2}$ was higher than $95 \%$ in ARDS patients. The proportion of respondents that would lower $\mathrm{FiO}_{2}$ is much lower if patients were presented with sepsis, cardiac and cerebral ischemia, or untreatable anemia. Unfortunately, we do not know whether respondents believe that oxygen is specifically harmful in patients with pre-existing acute lung injury or that higher oxygen levels are considered desirable in patients with ischemia or anemia. The latter hypothesis appears plausible, even though hyperoxemia has been reported to induce important vasoconstriction, which may lead to a paradoxical decrease in oxygen delivery $[4,42]$.

The self-reported low tolerance for higher $\mathrm{PaO}_{2}$ or $\mathrm{SaO}_{2}$ than target levels appears to be in contrast with actual treatment of patients in the same three ICUs where the survey was conducted. Neither $\mathrm{FiO}_{2}$ nor PEEP was changed in the majority of cases when $\mathrm{PaO}_{2}$ was higher than $15 \mathrm{kPa}(112.5 \mathrm{mmHg})$ and $\mathrm{FiO}_{2}$ was $40 \%$ or lower. In cases when $\mathrm{FiO}_{2}$ was $40 \%$ to $100 \%$, ventilator settings were adjusted more often, but even in these circumstances, hyperoxemia was accepted in approximately $20 \%$. Considering the absence of definitive guidelines and robust controlled clinical evidence, this behavior in itself may still be justifiable [43]. However, the contrast between self-reported attitudes towards oxygen therapy on the one hand and actual treatment by the same healthcare workers on the other hand is striking.

The findings about oxygenation in ICU patients are consistent with previous findings from single center studies, showing that hyperoxemia was frequently present in mechanically ventilated patients and seldom led to adjustment of ventilator settings [31,32]. Clinicians may have specific reasons not to adjust ventilator settings when $\mathrm{PaO}_{2}$ levels are higher than the target range. Indeed, we identified a considerable number of cases in which a presumed inadequate adjustment ultimately proved reasonable in the subsequent ABG sample (e.g., high $\mathrm{PaO}_{2}$ followed by an increase in $\mathrm{FiO}_{2}$, but resulting in a lower $\mathrm{PaO}_{2}$ ). These cases may reflect scenarios in which clinicians anticipate deterioration in oxygenation or otherwise consider $\mathrm{PaO}_{2}$ values as erroneous (e.g., arguably high $\mathrm{PaO}_{2}$ - see Table 4, row $\mathrm{PaO}_{2}>30$ ) or not representative for the current situation of a patient. Alternatively, it may be argued that hypoxemia harbors greater inherent hazards than hyperoxemia [3].

The differences between self-reported attitudes and actual treatment of patients should be interpreted with caution. First, the cases presented to the respondents included only limited details and do not reflect the complexity of clinical situations in daily practice. Further, we presented $\mathrm{SaO}_{2}$ and $\mathrm{PaO}_{2}$ categorized in ranges that were arbitrarily chosen. This may have influenced interpretation of the hypothetical cases. Second, ICU clinicians may have given more favorable responses in the online questionnaire due to social desirability and attention bias, although this is less likely as anonymous evaluation was secured. Third, the respondents were asked for the minimum allowable range in a specific ARDS case vignette, which may not reflect their beliefs regarding oxygen therapy in general. In the analysis of actually achieved 
Table 4 Adjustment of mechanical ventilation settings following ABG analysis

\begin{tabular}{|c|c|c|c|c|c|c|c|c|c|c|c|c|c|c|c|}
\hline \multirow[b]{2}{*}{$\mathrm{PaO}_{2}$} & \multicolumn{3}{|c|}{$\mathrm{FiO}_{2} 25 \%$ to $40 \%(n=37,172)$} & \multicolumn{3}{|c|}{$\mathrm{FiO}_{2} 40 \%$ to $60 \%(n=23,466)$} & \multicolumn{3}{|c|}{$\mathrm{FiO}_{2} 60 \%$ to $80 \%(n=4,318)$} & \multicolumn{3}{|c|}{$\mathrm{FiO}_{2} 80 \%$ to $100 \%(n=2,041)$} & \multicolumn{3}{|c|}{ Total $(n=68,222)$} \\
\hline & \multicolumn{3}{|c|}{$13.4(4.1)$} & \multicolumn{3}{|c|}{$12.6(5.2)$} & \multicolumn{3}{|c|}{$12.3(6.6)$} & \multicolumn{3}{|c|}{$16.0(13.7)$} & \multicolumn{3}{|c|}{$13.1(5.2)$} \\
\hline $\mathrm{SpO}_{2}$ & \multicolumn{3}{|c|}{$98.0(2.9)$} & \multicolumn{3}{|c|}{$96.5(3.8)$} & \multicolumn{3}{|c|}{$94.3(6.3)$} & \multicolumn{3}{|c|}{$89.7(12.5)$} & \multicolumn{3}{|c|}{$96.9(4.6)$} \\
\hline PEEP & \multicolumn{3}{|c|}{$5.6(3.4)$} & \multicolumn{3}{|c|}{$7.3(4.4)$} & \multicolumn{3}{|c|}{$9.1(5.6)$} & \multicolumn{3}{|c|}{$9.0(6.3)$} & \multicolumn{3}{|c|}{$6.5(4.2)$} \\
\hline $\begin{array}{l}\mathrm{PaO}_{2} \\
\text { range (kPa) }\end{array}$ & $\begin{array}{l}\text { Delta } \\
\mathrm{FiO}_{2}(\%)\end{array}$ & $\begin{array}{l}\text { Delta PEEP } \\
\left(\mathrm{cm} \mathrm{H}_{2} \mathrm{O}\right)\end{array}$ & $\begin{array}{l}\text { No decrease } \\
\text { in } \mathrm{FiO}_{2} \text { or } \\
\text { PEEP (\%) }\end{array}$ & $\begin{array}{l}\text { Delta } \\
\mathrm{FiO}_{2}(\%)\end{array}$ & $\begin{array}{l}\text { Delta PEEP } \\
\left(\mathrm{cm} \mathrm{H}_{2} \mathrm{O}\right)\end{array}$ & $\begin{array}{l}\text { No decrease } \\
\text { in } \mathrm{FiO}_{2} \text { or } \\
\text { PEEP (\%) }\end{array}$ & $\begin{array}{l}\text { Delta } \\
\mathrm{FiO}_{2}(\%)\end{array}$ & $\begin{array}{l}\text { Delta PEEP } \\
\left.\text { (cm } \mathrm{H}_{2} \mathrm{O}\right)\end{array}$ & $\begin{array}{l}\text { No decrease } \\
\text { in } \mathrm{FiO}_{2} \text { or } \\
\text { PEEP (\%) }\end{array}$ & $\begin{array}{l}\text { Delta } \\
\mathrm{FiO}_{2}(\%)\end{array}$ & $\begin{array}{l}\text { Delta PEEP } \\
\left(\mathrm{cm} \mathrm{H}_{2} \mathrm{O}\right)\end{array}$ & $\begin{array}{l}\text { No decrease } \\
\text { in } \mathrm{FiO}_{2} \text { or } \\
\text { PEEP (\%) }\end{array}$ & $\begin{array}{l}\text { Delta } \\
\mathrm{FiO}_{2}(\%)\end{array}$ & $\begin{array}{l}\text { Delta PEEP } \\
\left.\text { (cm } \mathrm{H}_{2} \mathrm{O}\right)\end{array}$ & $\begin{array}{l}\text { No decrease } \\
\text { in } \mathrm{FiO}_{2} \text { or } \\
\text { PEEP (\%) }\end{array}$ \\
\hline$<7$ & $\begin{array}{l}+6.1 \\
(13.8)\end{array}$ & $+0.3(3.2)$ & 87.6 & $\begin{array}{l}+5.4 \\
(13.2)\end{array}$ & $+0.7(3.7)$ & 81.3 & $\begin{array}{l}+2.0 \\
(14.5)\end{array}$ & $+0.6(6.0)$ & 86.3 & $\begin{array}{l}-7.0 \\
(16.8)\end{array}$ & $+1.0(6.7)$ & 76.9 & $\begin{array}{l}+3.0 \\
(14.8)\end{array}$ & $+0.7(4.3)$ & 83.3 \\
\hline 7 to 10 & $\begin{array}{l}+2.6 \\
(6.7)\end{array}$ & $+0.1(3.1)$ & 81.9 & $\begin{array}{l}+1.6 \\
(7.3)\end{array}$ & $+0.2(4.0)$ & 80.3 & $\begin{array}{l}-0.2 \\
(9.4)\end{array}$ & $+0.3(5.2)$ & 80.8 & $\begin{array}{l}-6.7 \\
(14.8)\end{array}$ & $+0.1(5.9)$ & 76.5 & $\begin{array}{l}+1.3 \\
(8.3)\end{array}$ & $+0.2(3.8)$ & 80.8 \\
\hline 10 to 15 & $\begin{array}{l}+0.6 \\
(4.9)\end{array}$ & $-0.2(2.7)$ & 72.9 & $\begin{array}{l}-1.5 \\
(6.6)\end{array}$ & $-0.2(3.8)$ & 48.2 & $\begin{array}{l}-5.2 \\
(9.2)\end{array}$ & $+0.1(4.9)$ & 33.7 & $\begin{array}{l}-15.6 \\
(19.2)\end{array}$ & $+0.4(5.7)$ & 31.1 & $\begin{array}{l}-0.6 \\
(6.7)\end{array}$ & $-0.1(3.2)$ & 62.3 \\
\hline 15 to 20 & $\begin{array}{l}-0.3 \\
(5.1)\end{array}$ & $-0.3(2.7)$ & 65.0 & $\begin{array}{l}-4.8 \\
(7.2)\end{array}$ & $-0.3(3.3)$ & 25.1 & $\begin{array}{l}-11.2 \\
(11.4)\end{array}$ & $+0.1(4.7)$ & 13.5 & $\begin{array}{l}-20.4 \\
(20.5)\end{array}$ & $+0.0(4.7)$ & 23.6 & $\begin{array}{l}-2.0 \\
(7.3)\end{array}$ & $-0.2(3.0)$ & 52.8 \\
\hline 20 to 25 & $\begin{array}{l}-1.2 \\
(6.4)\end{array}$ & $-0.2(2.4)$ & 54.2 & $\begin{array}{l}-6.1 \\
(9.0)\end{array}$ & $-0.4(3.0)$ & 22.1 & $\begin{array}{l}-12.7 \\
(12.4)\end{array}$ & $-0.4(5.3)$ & 11.8 & $\begin{array}{l}-25.9 \\
(21.7)\end{array}$ & $-0.1(4.8)$ & 21.3 & $\begin{array}{l}-4.2 \\
(10.1)\end{array}$ & $-0.3(2.9)$ & 40.4 \\
\hline 25 to 30 & $\begin{array}{l}-1.6 \\
(7.0)\end{array}$ & $-0.4(2.8)$ & 51.6 & $\begin{array}{l}-7.2 \\
(9.6)\end{array}$ & $-0.3(2.7)$ & 18.8 & $\begin{array}{l}-19.0 \\
(12.1)\end{array}$ & $-0.4(3.8)$ & 9.2 & $\begin{array}{l}-25.3 \\
(21.6)\end{array}$ & $-0.1(4.8)$ & 22.9 & $\begin{array}{l}-7.1 \\
(12.2)\end{array}$ & $-0.3(2.9)$ & 32.0 \\
\hline$>30$ & $\begin{array}{l}-1.0 \\
(6.6)\end{array}$ & $-0.4(4.0)$ & 69.8 & $\begin{array}{l}-3.5 \\
(9.6)\end{array}$ & $-0.4(4.5)$ & 43.0 & $\begin{array}{l}-15.4 \\
(15.8)\end{array}$ & $+0.3(5.7)$ & 24.8 & $\begin{array}{l}-33.6 \\
(23.2)\end{array}$ & $-0.4(4.0)$ & 14.3 & $\begin{array}{l}-5.7 \\
(15.9)\end{array}$ & $-0.3(4.2)$ & 51.6 \\
\hline
\end{tabular}

Data are means $( \pm \mathrm{SD})$, unless stated otherwise. Delta = difference between two successive $A B G$ samples. 
oxygenation, we studied all patients independent of admission diagnosis. Also, response rates for the survey were relatively modest. However, the profession distribution in the group of respondents closely reflects a typical staff constitution in a general ICU in the Netherlands, which reduces the chance of sampling bias. In the Dutch clinical setting where respiratory therapists are not available, it is often the bedside nurse that responds first to changes in oxygenation. Therefore, the opinions of ICU nurses about oxygen therapy are important in the actual care of critically ill patients [39]. Finally, some ABG samples, taken shortly after ICU arrival, may reflect oxygen therapy initiated on the operating room and influenced by anesthesiological ventilation strategies. However, successive ventilator adjustments were all recorded on the ICU and were supervised by critical care physicians. Therefore, high $\mathrm{PaO}_{2}$ values in the direct postoperative period are not a plausible explanation for the low proportion of hyperoxic ABG samples not followed by adaptation of the ventilator settings.

Strengths of this study include the large sample of questionnaire responses and the extensive set of $\mathrm{ABG}$ data, derived from the same ICUs where the questionnaire was conducted. This facilitated a comprehensive comparison between self-reported attitudes and actual practices of oxygen therapy for both physicians and nurses. Further, the design of the present questionnaire closely resembles previous surveys from Canada and Australia, thereby exploring geographical patterns and trends in time concerning oxygen therapy. Our study extends these data as we have assessed objective data in our analysis including the successively measured $\mathrm{PaO}_{2}$ after $\mathrm{FiO}_{2}$ adjustment. This allows further estimation of the effects of recorded $\mathrm{FiO}_{2}$ adjustments in comparison with previous data [32].

\section{Conclusions}

This study shows that most clinicians acknowledge the potential adverse effects of prolonged exposure to hyperoxia, in accordance with emerging evidence for pulmonary toxicity and increased risk of poor outcome in both humans and animals caused by excessive oxygenation $[2,4,6,8,16,18,20,35,44]$. However, objective data also suggest that clinicians did not consistently accommodate this conception in actual clinical practice and a large proportion of patients was exposed to arterial oxygen levels higher than self-reported as acceptable by nurses and physicians. Additional education, feedback, and implementation strategies, aimed at careful titration of oxygen, may therefore be an effective approach for strict adherence to oxygenation targets [45]. Studies on the effects of different target ranges for $\mathrm{PaO}_{2}$ on clinically relevant endpoints are needed to guide ICU professionals on how much oxygen should be administered to their patients.

\section{Additional file} Additional file 1: Questionnaire (translated from Dutch) as sent to
all participants. The questionnaire is a modified and comprehensive version of previously used questionnaires $[27,28]$.

\section{Abbreviations}

ABG: arterial blood gas; $\mathrm{FiO}_{2}$ : fractions of inspired oxygen; ICU: intensive care unit; $\mathrm{PaO}_{2}$ : partial arterial oxygen pressure; PDMS: patient data management system; PEEP: positive end-expiratory pressure; $\mathrm{SaO}_{2}$ : arterial oxygen saturation.

\section{Competing interests}

The authors declare that they have no competing interests.

\section{Authors' contributions}

HJFH drafted the manuscript and participated in the conception and design, and collection, analysis, and interpretation of the data. MJS and PHvdV participated in the conception and design, interpretation of data, and critical revision of the article for important intellectual content. RJB was involved in the collection, assembly and interpretation of data, and critical revision. NPJ participated in the interpretation of data and critical revision. EdJ and DJvW were involved in the conception and design, interpretation and collection of data, and critical revision. All authors read and approved the final

manuscript.

\section{Acknowledgements}

This work was supported by an unrestricted grant from the Netherlands Organisation for Health Research and Development (ZonMw).

\section{Author details}

'Department of Intensive Care Medicine, Leiden University Medical Center, Post Box 9600, Leiden 2300, RC, The Netherlands. '2Laboratory of Experimental Intensive Care and Anesthesiology, Academic Medical Center, Amsterdam 1105, AZ, The Netherlands. ${ }^{3}$ Department of Intensive Care Medicine, Academic Medical Center, Amsterdam 1105AZ, The Netherlands. ${ }^{4}$ Department of Intensive Care Medicine, Onze Lieve Vrouwe Gasthuis, Amsterdam 1091, AC, The Netherlands.

Received: 1 April 2014 Accepted: 27 June 2014

Published: 25 July 2014

\section{References}

1. Altemeier WA, Sinclair SE: Hyperoxia in the intensive care unit: why more is not always better. Curr Opin Crit Care 2007, 13:73-78.

2. de Jonge E, Peelen L, Keijzers PJ, Joore H, de Lange D, van der Voort PH, Bosman RJ, de Waal RA, Wesselink R, de Keizer NF: Association between administered oxygen, arterial partial oxygen pressure and mortality in mechanically ventilated intensive care unit patients. Crit Care 2008, 12:R156.

3. Eastwood G, Bellomo R, Bailey M, Taori G, Pilcher D, Young P, Beasley R: Arterial oxygen tension and mortality in mechanically ventilated patients. Intensive Care Med 2012, 38:91-98.

4. Farquhar $H$, Weatherall M, Wijesinghe M, Perrin K, Ranchord A, Simmonds $M$, Beasley R: Systematic review of studies of the effect of hyperoxia on coronary blood flow. Am Heart J 2009, 158:371-377.

5. Hovaguimian F, Lysakowski C, Elia N, Tramer MR: Effect of intraoperative high inspired oxygen fraction on surgical site infection, postoperative nausea and vomiting, and pulmonary function: systematic review and meta-analysis of randomized controlled trials. Anesthesiology 2013, 119:303-316.

6. Kilgannon $\mathrm{JH}$, Jones AE, Shapiro NI, Angelos MG, Milcarek B, Hunter K, Parrillo JE, Trzeciak S, E EMSRN: Association between arterial hyperoxia following resuscitation from cardiac arrest and in-hospital mortality. JAMA 2010, 303:2165-2171.

7. Bellomo R, Bailey M, Eastwood GM, Nichol A, Pilcher D, Hart GK, Reade MC, Egi M, Cooper DJ, Study of Oxygen in Critical Care (SOCC) Group: Arterial hyperoxia and in-hospital mortality after resuscitation from cardiac arrest. Crit Care 2011, 15:R90. 
8. Janz DR, Hollenbeck RD, Pollock JS, McPherson JA, Rice TW: Hyperoxia is associated with increased mortality in patients treated with mild therapeutic hypothermia after sudden cardiac arrest. Crit Care Med 2012, 40:3135-3139.

9. Ihle JF, Bernard S, Bailey MJ, Pilcher DV, Smith K, Scheinkestel CD: Hyperoxia in the intensive care unit and outcome after out-of-hospital ventricular fibrillation cardiac arrest. Crit Care Resusc 2013, 15:186-190.

10. Wijesinghe M, Perrin K, Ranchord A, Simmonds M, Weatherall M, Beasley R: Routine use of oxygen in the treatment of myocardial infarction: systematic review. Heart 2009, 95:198-202.

11. Young P, Beasley R, Bailey M, Bellomo R, Eastwood GM, Nichol A, Pilcher DV, Yunos NM, Egi M, Hart GK, Reade MC, Cooper DJ, Study of Oxygen in Critical Care (SOCC) Group: The association between early arterial oxygenation and mortality in ventilated patients with acute ischaemic stroke. Crit Care Resusc 2012, 14:14-19.

12. Rachmale $S, L i$ G, Wilson G, Malinchoc M, Gajic O: Practice of excessive $\mathrm{FiO}_{2}$ and effect on pulmonary outcomes in mechanically ventilated patients with acute lung injury. Respir Care 2012, 57:1887-1893.

13. Raj R, Bendel S, Reinikainen M, Kivisaari R, Siironen J, Lang M, Skrifvars M: Hyperoxemia and long-term outcome after traumatic brain injury. Crit Care 2013, 17:R177.

14. Rincon F, Kang J, Maltenfort M, Vibbert M, Urtecho J, Athar MK, Jallo J, Pineda CC, Tzeng D, McBride W, Bell R: Association between hyperoxia and mortality after stroke: a multicenter cohort study. Crit Care Med 2013, 42:387-396.

15. Rincon F, Kang J, Vibbert M, Urtecho J, Athar MK, Jallo J: Significance of arterial hyperoxia and relationship with case fatality in traumatic brain injury: a multicentre cohort study. J Neurol Neurosurg Psychiatry 2013, 85:799-805

16. Baleeiro CE, Wilcoxen SE, Morris SB, Standiford TJ, Paine R 3rd: Sublethal hyperoxia impairs pulmonary innate immunity. I Immunol 2003, 171:955-963.

17. Kikuchi Y, Tateda K, Fuse ET, Matsumoto T, Gotoh N, Fukushima J, Takizawa $H$, Nagase T, Standiford TJ, Yamaguchi K: Hyperoxia exaggerates bacterial dissemination and lethality in Pseudomonas aeruginosa pneumonia. Pulm Pharmacol Ther 2009, 22:333-339.

18. Li LF, Liao SK, Ko YS, Lee CH, Quinn DA: Hyperoxia increases ventilatorinduced lung injury via mitogen-activated protein kinases: a prospective, controlled animal experiment. Crit Care 2007, 11:R25.

19. Makena PS, Luellen CL, Balazs L, Ghosh MC, Parthasarathi K, Waters CM, Sinclair SE: Preexposure to hyperoxia causes increased lung injury and epithelial apoptosis in mice ventilated with high tidal volumes. Am J Physiol Lung Cell Mol Physiol 2010, 299:L711-L719.

20. Nagato A, Silva FL, Silva AR, Bezerra FS, Oliveira ML, Bello-Klein A, Cristovao Porto L, Santos Valenca S: Hyperoxia-induced lung injury is dose dependent in Wistar rats. Exp Lung Res 2009, 35:713-728.

21. Tateda K, Deng JC, Moore TA, Newstead MW, Paine R 3rd, Kobayashi N, Yamaguchi K, Standiford TJ: Hyperoxia mediates acute lung injury and increased lethality in murine Legionella pneumonia: the role of apoptosis. J Immunol 2003, 170:4209-4216.

22. Winslow RM: Oxygen: the poison is in the dose. Transfusion 2013, 53:424-437.

23. Maclntyre NR, Cook DJ, Ely EW Jr, Epstein SK, Fink JB, Heffner JE, Hess D, Hubmayer RD, Scheinhorn DJ, American College of Chest Physicians; American Association for Respiratory Care; American College of Critical Care Medicine: Evidence-based guidelines for weaning and discontinuing ventilatory support: a collective task force facilitated by the American College of Chest Physicians; the American Association for Respiratory Care; and the American College of Critical Care Medicine. Chest 2001, 120:375S-395S

24. Martin DS, Grocott MP: Oxygen therapy in critical illness: precise control of arterial oxygenation and permissive hypoxemia. Crit Care Med 2013, 41:423-432.

25. Gillbert-Kawai ET, Mitchell K, Martin D, Carlisle J, Grocott MP: Permissive hypoxaemia versus normoxaemia for mechanically ventilated critically ill patients. Cochrane Database Syst Rev 2014, 5:CD009931.

26. O'Driscoll BR, Howard LS, Davison AG, British Thoracic S: BTS guideline for emergency oxygen use in adult patients. Thorax 2008, 63(Suppl 6):vi1-vi68.

27. Eastwood GM, Reade MC, Peck L, Jones D, Bellomo R: Intensivists' opinion and self-reported practice of oxygen therapy. Anaesth Intensive Care 2011, 39:122-126.
28. Mao C, Wong DT, Slutsky AS, Kavanagh BP: A quantitative assessment of how Canadian intensivists believe they utilize oxygen in the intensive care unit. Crit Care Med 1999, 27:2806-2811

29. Tobin MJ: Mechanical ventilation. N Engl J Med 1994, 330:1056-1061.

30. Brower RG, Lanken PN, Maclntyre N, Matthay MA, Morris A, Ancukiewicz M, Schoenfeld D, Thompson BT, National Heart L, Blood Institute ACTN: Higher versus lower positive end-expiratory pressures in patients with the acute respiratory distress syndrome. N Engl J Med 2004, 351:327-336.

31. Suzuki S, Eastwood GM, Peck L, Glassford NJ, Bellomo R: Current oxygen management in mechanically ventilated patients: a prospective observational cohort study. J Crit Care 2013, 28:647-654.

32. de Graaff AE, Dongelmans DA, Binnekade JM, de Jonge E: Clinicians' response to hyperoxia in ventilated patients in a Dutch ICU depends on the level of $\mathrm{FiO}_{2}$. Intensive Care Med 2011, 37:46-51.

33. Panwar R, Capellier G, Schmutz N, Davies A, Cooper DJ, Bailey M, Baguley D, Pilcher V, Bellomo R: Current oxygenation practice in ventilated patients an observational cohort study. Anaesth Intensive Care 2013, 41:505-514.

34. Brower RG, Matthay MA, Morris A, Schoenfeld D, Thompson BT, Wheeler A, Wiedemann HP, Arroliga AC, Fisher CJ, Komara JJ, Perez-Trepichio P, Parsons PE, Wolkin R, Welsh C, Fulkerson WJ, Maclntyre N, Mallatratt L, Sebastian M, McConnell R, Wilcox C, Govert J, Thompson D, Clemmer T, Davis R, Orme J, Weaver L, Grissom C, Eskelson M, Young M, Gooder V, et al: Ventilation with lower tidal volumes as compared with traditional tidal volumes for acute lung injury and the acute respiratory distress syndrome. $N$ Engl I Med 2000, 342:1301-1308.

35. Barazzone C, Horowitz S, Donati YR, Rodriguez I, Piguet PF: Oxygen toxicity in mouse lung: pathways to cell death. Am J Respir Cell Mol Biol 1998, 19:573-581.

36. Gore A, Muralidhar M, Espey MG, Degenhardt K, Mantell LL: Hyperoxia sensing: from molecular mechanisms to significance in disease. J Immunotoxicol 2010, 7:239-254.

37. Nagato AC, Bezerra FS, Lanzetti M, Lopes AA, Silva MA, Porto LC, Valenca SS: Time course of inflammation, oxidative stress and tissue damage induced by hyperoxia in mouse lungs. Int J Exp Pathol 2012, 93:269-278.

38. Sinclair SE, Altemeier WA, Matute-Bello G, Chi E: Augmented lung injury due to interaction between hyperoxia and mechanical ventilation. Crit Care Med 2004, 32:2496-2501.

39. Eastwood GM, Reade MC, Peck L, Baldwin I, Considine J, Bellomo R: Critical care nurses' opinion and self-reported practice of oxygen therapy: a survey. Aust Crit Care 2012, 25:23-30.

40. Blakeman TC: Evidence for oxygen use in the hospitalized patient: is more really the enemy of good? Respir Care 2013, 58:1679-1693.

41. Jubran A, Tobin MJ: Reliability of pulse oximetry in titrating supplemental oxygen therapy in ventilator-dependent patients. Chest 1990, 97:1420-1425

42. Bak Z, Sjoberg F, Rousseau A, Steinvall I, Janerot-Sjoberg B: Human cardiovascular dose-response to supplemental oxygen. Acta Physiol (Oxf) 2007, 191:15-24.

43. Budinger GR, Mutlu GM: Balancing the risks and benefits of oxygen therapy in critically III adults. Chest 2013, 143:1151-1162.

44. Davis DP, Meade W, Sise MJ, Kennedy F, Simon F, Tominaga G, Steele J, Coimbra R: Both hypoxemia and extreme hyperoxemia may be detrimental in patients with severe traumatic brain injury. J Neurotrauma 2009, 26:2217-2223.

45. Suzuki S, Eastwood GM, Glassford NJ, Peck L, Young H, Garcia-Alvarez M, Schneider AG, Bellomo R: Conservative oxygen therapy in mechanically ventilated patients: a pilot before-and-after trial. Crit Care Med 2014, 42:1414-1422.

doi:10.1186/s13613-014-0023-y

Cite this article as: Helmerhorst et al: Self-reported attitudes versus actual practice of oxygen therapy by ICU physicians and nurses. Annals of Intensive Care 2014 4:23. 